УДК 37.013 .73

Крись Андрій Іванович, викладач кафедри бальної хореографії Київського національного університету культури і мистецтв ORCID 0000-0002-5413-1992 Krys.rumba@gmail.com

\title{
ТЕНДЕНЦІЇ РОЗВИТКУ ДРАМАТУРГІЇ СЦЕНІЧНОЇ БАЛЬНОЇ ХОРЕОГРАФІЇ У КОНТЕКСТІ СВІТОВИХ ПРОЦЕСІВ
}

\begin{abstract}
Мета статті - визначити тенденції та перспективи розвитку драматургії сценічної бальної хореографії у контексті сучасних світових соціомистецьких процесів. Методологія дослідження. Визначення особливостей розвитку драматургії сценічної бальної хореографії на сучасному етапі здійснено на основі синтезу різних методологічних підходів: культурологічного, який посприяв осмисленню процесу формування та розвитку сценічної бальної хореографії в історичній ретроспективі, виявленню взаємозв'язків та взаємовпливів світових соціомистецьких і соціокультурних змін у процесі еволюціонування теоретичних засад та практичних набутків драматичного напряму сценічної бальної хореографії; мистецтвознавчого, за допомогою якого було визначено лексичну, стильову та жанрову специфіку розвитку сценічного бального танцю, відповідно до тенденції розвитку драматургії сценічної бальної хореографії у контексті світових процесів та національних особливостей. Наукова новизна. Виявлено основні закономірності та тенденції розвитку драматургії сценічної бальної хореографії початку XXI ст.; визначено специфіку постановок сценічної бальної хореографії на сучасному етапі та пріоритетні напрямки діяльності хореографа-постановника; прогнозовано можливі перспективи розвитку драматургії сценічної бальної хореографії у контексті сучасних світових соціомистецьких процесів. Висновки. Перспективними тенденціями розвитку драматургії сценічної бальної хореографії XXI ст. $є$ посилення ролі танцювальних драматургів у процесі створення матеріалу для танцю та руху (розвиток творчих стратегій, осмислення взаємозв'язку між підходами до композиційних можливостей, обгрунтування у процесі репетицій, урахування індивідуальних якостей танцюристів та здатність відчувати засоби сприйняття); залучення до динамічного постановочного процесу митців різних дисциплін та співпраця 3 танцювальними драматургами, задля отримання унікальної суміші художніх бачень у сценічній бальній хореографії; тенденція до використання танцювальної драматургії у галузі хореографічної освіти та професійній діяльності танцюристів, як засіб розширення хореографічної перспективи. Пріоритетним у діяльності хореографа-постановника на сучасному етапі визначено поєднання естетичного досвіду з критичним аналізом, цілеспрямоване та активне спостереження за навколишнім середовищем, задля того, аби переступити межі уявлення відомих образів та формувати нові погляди і перспективи.
\end{abstract}

Ключові слова: танцювальна драматургія, сценічна бальна хореографії, соціомистецький простір, хореограф-постановник.

Крысь Андрей Иванович, преподаватель кафедры бальной хореографии Киевского национального университет культуры и искусств процессов

Тенденции развития драматургии сценической бальной хореографии в контексте мировых

Цель статьи - определить тенденции и перспективы развития драматургии сценической бальной хореографии в контексте современных мировых процессов социального искусства. Методология исследования. Определение особенностей развития драматургии сценической бальной хореографии на современном этапе осуществлено на основе синтеза различных методологических подходов: культурологического, который помог осмыслению процесса формирования и развития сценической бальной хореографии в исторической ретроспективе, выявлению взаимосвязей и взаимовлияния мировых социокультурных изменений в процессе эволюционирования теоретических основ и практических достижений драматического направления сценического бальной хореографии; искусствоведческого, с помощью которого было определено лексическую, стилевую и жанровую специфику развития сценического бального танца, в соответствии с тенденцией развития драматургии сценической бальной хореографии в контексте мировых процессов и национальных особенностей. Научная новизна. Выявлены основные закономерности и тенденции развития драматургии сценической бальной хореографии начала XXI в.; определена специфика постановок сценической бальной хореографии на современном этапе и приоритетные направления деятельности хореографа-постановщика; спрогнозированны возможные перспективы развития драматургии сценической бальной хореографии в контексте современных мировых процес сов социального искусства. Выводы. Перспективными тенденциями развития драматургии сценической бальной хореографии XXI века является усиление роли танцевальных драматургов в процессе создания материала для танца и движения (развитие творческих стратегий, осмысление взаимосвязи между подходами к композиционных возможностей,

(C) Крись А. І., 2019 
обоснование в процессе репетиций, учета индивидуальных качеств танцоров и способность чувствовать средства восприятия); привлечение к динамичному постановочному процессу художников разных дисциплин и сотрудничество с танцевальными драматургами, для получения уникальной смеси художественных видений в сценической бальной хореографии; тенденция к использованию танцевальной драматургии в области хореографического образования и профессиональной деятельности танцоров, как средство расширения хореографической перспективы. Приоритетным в деятельности хореографа-постановщика на современном этапе определены сочетание эстетического опыта с критическим анализом, целенаправленное и активное наблюдение за окружающей средой, для того, чтобы переступить пределы представления известных образов и формировать новые взгляды и перспективы.

Ключевые слова: танцевальная драматургия, сценическая бальная хореография, искусство в социальном пространстве, хореограф-постановщик.

Krys Andrey, Lecturer, Ballroom Choreography Department, Kiev National University of Culture and Arts Trends in the development of dramatic stage ballet choreography in the context of global processes

The purpose of the article is to identify trends and prospects for the development of dramatic art of stage ball choreography in the context of modern world processes of social art. Methodology. Features of dramatic development of stage ballroom choreography at the present stage are based on the synthesis of various methodological approaches: cultural, which helped understanding the process of forming and developing stage ballroom choreography in historical retrospective, identifying interconnections and mutual influence of world sociocultural changes in the process of evolving the theoretical foundations and practical achievements of dramatic directions of stage ball choreography; art critic, with the help of which the lexical, stylistic and genre specificity of the development of stage ballroom dance was determined, in accordance with the trend of dramatic stage ballroom choreography in the context of world processes and national characteristics. Scientific novelty. The main regularities and trends in the development of dramatic art of stage ballet choreography of the early 21 st century are revealed; The specifics of the stage ballroom choreography at the current stage and the priority directions of the choreographer's director were determined; possible prospects for the development of dramatic stage ballet choreography in the context of the modern world processes of social art are predicted. Conclusions. The promising trends in the dramatic development of stage ballet choreography of the $21 \mathrm{st}$ century is the strengthening of the role of dance dramatists in the process of creating material for dance and movement (developing creative strategies, understanding the relationship between approaches to compositional possibilities, substantiating the process of rehearsing, taking into account the individual qualities of dancers and the ability to feel means of perception) ; attraction to the dynamic staging process of artists of different disciplines and cooperation with dance playwrights, to obtain a unique blend of artistic visions in the stage ballroom choreography; the tendency to use dance drama in the field of choreographic education and the professional activities of dancers as a means of broadening the choreographic perspective. The combination of aesthetic experience with critical analysis, purposeful and active observation of the environment, in order to transcend the limits of the representation of well-known images and form new views and perspectives, are identified as a priority in the choreographer's work at the present stage.

Key words: dance drama, stage ballroom choreography, art in social space, choreographer.

Актуальність теми дослідження. Специфіка драматургії сценічної бальної хореографії галузь й на сьогодні маловивчена. Відсутність грунтовних науково-теоретичних праць на навчальнометодичної літератури присвячених питанням генези драматургії сценічної бальної хореографії, особливостям та принципам роботи балетмейстрів-постановників, аналізу традиційних та інноваційних драматургічних рішень створення сценічних хореографічних творів, запропонованих та реалізованих відомими постановниками минулого та сучасності, значно ускладнює процес оволодіння основами професії хореографа-постановника у вищих мистецьких навчальних закладах, оскільки означені питання $€$ фундаментальними на вкрай необхідними в їх майбутній творчій діяльності. Дослідження тенденцій розвитку драматургії сценічної бальної хореографії на сучасному етапі, відтак, позиціонуємо актуальною та необхідною частиною їі подальшого розвитку в умовах соціокультурного та соціомистецького простору XXI ст.

Мета статті - визначити тенденції та перспективи розвитку драматургії сценічної бальної хореографії у контексті сучасних світових соціомистецьких процесів.

Аналіз публікацій засвідчує, що у вітчизняному науковому просторі проблематика танцювальної драматургії загалом та драматургії сценічної бальної хореографі зокрема, лишається одним із найменш досліджених аспектів хореографічного мистецтва. Натомість зарубіжні науковці розглядають та аналізують специфіку танцювальної драматургії 3 мистецтвознавчих, культурологічних та хореологічних позицій, що засвідчує міждисциплінарний характер означеного питання, позиціонування драматургії у хореографічному мистецтві базовою, глобальною структурою, що надає танцювальній постановці форму та змісту. У контексті даного дослідження найбільш актуальними виявилися праці П. Хансена «Акт рендеринга: драматургія танцю та руху» («An Act of Rendering: Dance and Movement Dramaturgy», 2010 р.), Л. Ханса-Тіеса та Р. Примавезі «Драматургія 
на змінних засадах» («Dramaturgy on Shifting Grounds», 2009 р.), Н. Накаджима «Танцювальна хореографія як процес навчання» («Dance Dramaturgy as a Process of Learning», 2015 р.), К. Профети «Драматургія руху: в роботі над танцювальними та руховими постановками» («Dramaturgy in Motion: At Work on Dance and Movement Performance», 2015 p.) та ін.

Виклад основного матеріалу. Драматургія руху - це мистецтво драматичної композиції

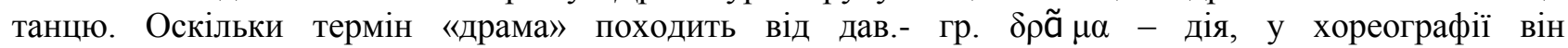
використовується у контексті жестів танцюристів, які є дією. Танцюристи застосовують різноманітні форми, негативний чи позитивний простір, текстури, ритмічні малюнки, драматичну енергію та емоції. У хореографічних композиціях поєднані елементи візуального, музичного, драматичного мистецтва та літератури. Вивчаючи використання цих елементів в інших видах мистецтва, танцюристи розвивають більш глибоке розуміння того, як застосовувати та маніпулювати ними у композиції рухів. Проте, варто зазначити, що ці елементи важливі не лише для танцювальних постановок - вони є природою танцю і взаємодіють з іншими видами мистецтва. Коли хореографи створюють візуальні музичні та драматичні постановки, вони втілюють форми та лінії, ритми $\mathrm{i}$ текстури оповіді, поезії та емоції, відтак танцюристи стають водночас і мистецтвознавцями, i музикантами, і художниками і оповідачами. Визнаючи і реагуючи на міждисциплінарний характер танцю, виконавці та хореографи всіх фонових рухів можуть підвищити свою динаміку роботи та художню чуттєвість.

У хореографічному мистецтві драматургія - це базова та глобальна структура, яка надає танцювальній постановці форму та зміст. Наприклад, відповідно до задуму постановника, драматична структура може складатися 3 танцювальної п'єси, або окремих сцен, частин чи моментів, організованих та показаних у розвитку (у хореографічному фрагментів, драматургія руху - це спосіб відображення інтенсивності частин або фразування).

Кожна хореографічна постановка має драматичну структуру - театральну, яка передає логічну дію (історію, сюжет) засобами хореографічної виразності або музичну, яка апріорі $є$ абстрактною (сюжет та історія відсутні) і демонструє естетичні танцювальні форми та якість руху, просторовий розподіл тощо. Наприклад, оповідно-хореографічні драматичні структури поділяються на: класичну (складається з введення, розвитку, кульмінації та закінчення); кругову (оповідь починається з кінця історії, а розвивається та закінчується, відповідно, всередині і на початку); інвертовану (розвиток історії з кінця до початку); рівну (відсутні зміни інтенсивності дій або конфлікту; лише сама дія); призупинену (історія швидко набуває драматичного піку, а потім стихає, щоб знову різко піднятися); фрагментарну (частини історії відображаються хаотично) та ін. Розрізняються також і загальні музично-хореографічні структури: частина А та контрастна частина Б; частина А, контрастна частина Б та повернення до частини А; введення, частина А, частина Б, перехід, частина А, частина Б, закінчення; сюїта - 6-ть частин, кожна з яких має власний ритм та характер; частини (теми) та варіації до них; постійна прогресія - єдиний унікальний фрагмент, у якому інтенсивність нарощується поступово від початку до кінця; фрагментарна і непередбачувана - кілька частин, порядок яких змінюється при кожному виконанні.

Варто зазначити, що наведені вище структури - лише окремі приклади, оскільки створення інноваційної драматургії рухів не обмежено.

Наприкінці XX - на початку XXI ст. посилюється роль танцювальних драматургів у складному процесі створення матеріалу для танцю та руху, до якого на сучасному етапі входить розвиток творчих стратегій, осмислення взаємозв'язку між підходами до композиційних можливостей, обгрунтування у процесі репетицій, урахування індивідуальних якостей танцюристів та здатність відчувати засоби сприйняття (від сенсорно-модальних і резонансних до реляційного виникнення та міжтекстового зв'язку) [3, 188]. Ця тенденція, безумовно, впливає і на зміни у традиційній діяльності хореографа-постановника - безпосередня творча співпраця хореографа 3 драматургом під час постановки хореографічного твору або виступу, у світовій практиці є відносно новим феноменом, сприйнятим і підтриманим протягом кількох останніх десятиліть спочатку лише деякими, а наразі - багатьма відомими хореографами.

У виконавському мистецтві і танці постдраматичного театру, традиційна ієрархія театральних елементів практично зникла, оскільки такі елементи як простір, світло, звук, музика, рухи та жести стають визначальними факторами, замість тексту і мають рівноцінний вплив у процесі роботи $[4,3]$. Нові драматургічні форми і навички, відтак набувають великого значення з точки зору практики, адже не підкріплюють підкореність всіх елементів одному, а існують у динамічному балансі, який має бути створений при кожному виконанні. 
Наприкінці XX ст. театр і танець вийшли за межі усталених параметрів форми і значно розширили перспективи того, що може бути театром і танцем. Це, у свою чергу, посприяло розвитку танцювальної драматургії. Як зазначає К. Профета, першим хто використав визначення «драматург танцю», був Р. Ходж, який працював із хореографом П. Бауш у Вупертальському театрі танцю (Tanztheater Wuppertal) в Німеччині $[6,7]$. Внесок П. Бауш у формування та розвиток нових тенденції танцю по всьому світу неможливо недооцінити - здійснивши революцію у жанрах, вона створила перші танцювальні опери «Орфей та Еврідіка» (1975р.), «Я зроблю тебе» (1974р.) та «Потанцюй зі мною» (1977р.), виключною особливістю яких була відповідність кожному персонажу оперного та балетного виконавця; здійснила постановку вистави «Весна священна» (1975 p., музика I. Стравінського), який на думку багатьох танцюристів є абсолютом у хореографічному мистецтві; ініціювала спільну тенденцію створення танцю та відкритий хореографічний процес, задля залучення вивчення сенсу поза ремеслом, яке відіграло важливу роль у танцювальній драматургії $[6,7]$.

У другій половині 90-х рр. ХХ ст. у Європі, танцювальні драматурги отримали статус своєрідних посередників між теорією та практикою, а на сучасному етапі очевидною стає необхідність нової трансформації - розміщення танцювального драматурга в середині творчого процесу, задля зміни чіткого і далекого бачення драматургії на «інтеграцію тіла драматургії у тіло процесу» $[1,33]$.

Кожна танцювальна постановка чи проект окремого хореографа мають різні потреби, а відтак драматург повинен виробити більш гнучку позицію співпраці для розвитку творчого процесу.

Наразі у репертуарі провідних європейських театрів представлено мюзикли, концертні та шоу-програми побудовані на лексиці бальної хореографії, драматургія яких хоча й тяжіє до класичних форм, все ж має яскраві інноваційні підходи.

Так, наприклад, на сцені «Ріccadilly Theatre» репрезентовано мюзикл «Танці без правил» («Strictly Ballroom»), у постановці режисера-хореографа Д. Макні за сценарієм Б. Лурманна (у головних ролях У. Янг, 3. Стреллен, Д. Лебей, М. Кердл та ін.). Варто зазначити, що даний мюзикл сценічна адаптація відомого австралійського художнього фільму режисера Б. Лурмана (1992р.), прем’єра якої відбулася у 2014 р. на сцені «Сіднейського ліричного театру» («Sydney Lyric Theatre», Австралія), а в 2016 р. відбулася британська прем’єра на сцені театру в Лідсі («West Yorkshire Playhouse»). Проте, сучасний варіант постановки отримав багаточисельні оновлення, які стосуються акторського складу, введення нових персонажів та хореографії. В основі мюзиклу - історія танцюриста Скота, чемпіона з бальних танців, який кидає виклик усім правилам та йде на поклик серця, щоб знайти не лише своє покликання в танці, а й справжнє кохання [7].

Безумовно одним 3 найяскравіших шоу, яке репрезентує найкращі зразки сучасної сценічної бальної хореографії є «Вогонь танго» («Tango Fire»), яке на сцені лондонського театру «Реacock Theatre» презентує одна 3 провідних міжнародних танцювальних компаній - «The Tango Fire Company» 3 Буенос-Айреса. Режисером-хореографом та провідним виконавцем компанії є відомий професійний танцюрист, чемпіон світу 3 танго - аргентинець Г. Корнехо, який окрім латиноамериканських танців досконально вивчав класичні та сучасні бальні, джазові та акробатичні техніки, а також особливості хореографічної композиції. Хореограф здійснює сценізацію художньої форми аргентинського танго, ніби прослідковуючи історію його формування від перших форм на вулицях Буенос-Айреса, до сучасних сценічних бальних постановок. В акторському складі «Тhе Tango Fire Company», окрім Г. Корнехо та його партнерки Г. Гейдіасci, ще десять відомих професійних танцюристів - переможці World Tango Champions Е. Дуізага та П. Пачета, Е. Лопес та Каміла-Алегрі, Н. Шелл та Н. Піццо, М. Бейлоіс та М. Спіна, Х. Фернандес та М. Вейлдменн.

Варто зазначити, що хореографічні шоу компанії «The Tango Fire Company» користуються величезною популярністю - з гастрольною програмою «Tango Fire» заплановано виступи не лише в країнах Європи, а й в США, Канаді, Австралії, Азії та Південній Африці, а новацією компанії стало шоу «Break the Tango», у якому завдяки творчій співпраці режисера-постановника Г. Корнехо та хореографа Бйорна «Буз» Мейєра було поєднано два абсолютно різні стилі танцю - танго та брейкданс. Аналізуючи сценічну бальну хореографію представлену в країнах Зхідної Європи, варто відзначити діяльність компанії «Strictly Theatre Co.», засновану в 2015 р. П. Ірвінгом. Ця компанія здійснює понад 100 постановок за рік.

Так, наприклад, компанією «Strictly Theatre Со» наразі представлено в репертуарній програмі такі сценічні постановки бальної хореографії як: «Dance is life» у постановці режисера i хореографа Д. Гілкісона (креативного директора «Strictly Come Dancing»), за участю Д. Перніса та Л. Маштак хореографічне шоу на італійську тематику побудоване на лексиці бальних та латиноамериканських танців Пасадобль, Вальс, Румба, Джайв та ін.; яскрава та гламурна шоу-програма «The ballroom boys» 
за участю легендарного британського танцюриста, вчителя та хореографа, який спеціалізується на латиноамериканських танцях А. Вейта та професійного виконавця бальних танців, італійського танцюриста В. Сімона (хореографія програми побудована на лексиці танців Квікстеп, Пасадобль,Фокстрот та Аргентинське танго) [7].

Неабиякою популярністю у відвідувачів «Dis Corn Hall» та «Lowestoft Marina Theatre» користуються танцювальні програми групи «Backlash ballroom» (хореограф Р. Міллер), у складі якої шість професійних танцюристів - переможців у латиноамериканській та європейській програмах. Найвідомішою танцювальною виставою $є$ «Strictly Movies», яка побудовані на хореографічній лексиці Вальсу, Квікстепу, Аргентинського танго і Чарльстона (у супроводі саундтреків відомих фільмів).

Варто зазначити, що у програмах вищих мистецьких навчальних закладів, які займаються професійною підготовкою хореографів, помітним $\epsilon$ велике розмежування між теорією і практикою, що спостерігається першочергово у ставленні студентів до навчальних дисциплін - техніці та хореографії ними приділяється набагато більше уваги, аніж історії та теорії танцю. На нашу думку, у контексті розвитку хореографічного мистецтва на сучасному етапі, доцільним $\epsilon$ формування уяви та встановлення взаємозв'язку між написанням, критичним мисленням і танцями, хореографією та постановками, безпосередньо під час навчального процесу, що посприяс отриманню всебічної фахової підготовки для вільного виявлення себе у творчості. Відтак, важливим є встановлення зв'язку між вивченим матеріалом з історії танців та безпосередньо репетиційним процесом.

Деякі американські та європейські вчителі танців активно інтегрують драматургічні практики у курси історії танців 3 метою впливу на хореографічну та виконавську практику. Наприклад, К. Крофт вважає, що «заняття 3 танців значно виграють, коли танцювальна драматургія поєднується 3 історією танців, адже створює більше простору для дискусії про постановку» $[2,189]$.

Танцювальна драматургія сприяє формуванню аналітичного мислення як невід'ємної частини танцю, адже є творчим процесам, в якому взаємопов'язані метафоричні, аналітичні та критичні дискурси поглинаються творчим процесом $[5,166]$. Таке поєднання (наукових знань про танець 3 діями) сприяе створенню інформованого художнього бачення.

Світовою тенденцією, що активно розвивається у хореографічному мистецтві $\epsilon$ використання драматургічного мислення протягом творчого процесу всіма учасниками хореографічної постановки. Наприклад, концепція творчої діяльності керівництва Бельгійського театру танців «Les Ballets C de La В», заснованого у 1984 р. А. Плейтелом - «цей танець для світу, а світ для всіх», заснована на принципі залучення до динамічного постановочного процесу митців різних дисциплін та тісній співпраці з танцювальними драматургами, задля отримання унікального поєдання художніх бачень у сценічній бальній хореографії.

Наразі, помітною стає тенденція до використання танцювальної драматургії у професійній діяльності танцюристів як засіб розширення хореографічної перспективи. Подібні новації привносять у практичну діяльність танцюристів роботу над теоретичним матеріалом (за рахунок критики та обговорення), що формує ясність намірів та забезпечує додатковими перевагами у процесі художнього вибору. Вибір зроблений виключно на технічній підготовці сприяє створенню приємних композицій, проте вони можуть бути протилежними намірам хореографа. У драматургічному ж мисленні, творчий акт вільно протікає через критичний дискурс та естетичний вибір, а дія мислення переходить у рух. Відтак, успішна художня хореографічна постановка не може бути створена лише 3 виключно інтелектуальних або практичних перспектив, а тому доцільніше буде не обмежувати їх, a синтезувати.

Оскільки критичний аналіз пов'язаний із синтезом вісцеральних та раціональних реакцій, головною метою постановника має стати поєднання естетичного досвіду 3 критичним аналізом, цілеспрямоване та активне спостереження за навколишнім середовищем, задля того, щоб переступити межі уявлення відомих образів та формувати нові погляди і перспективи. Б. Бауер зазначає, що практика художньої творчості виходить за межі звичайних норм і переходить в естетичну сферу «унікального досвіду» у «моменти призупинення концептуальних знань» $[1,37-38]$.

Висновки. Перспективними тенденціями розвитку драматургії сценічної бальної хореографії XXI ст. $є$ посилення ролі танцювальних драматургів у процесі створення матеріалу для танцю та руху (розвиток творчих стратегій, осмислення взаємозв'язку між підходами до композиційних можливостей, обгрунтування у процесі репетицій, урахування індивідуальних якостей танцюристів та здатність відчувати засоби сприйняття); залучення до динамічного постановочного процесу митців різних дисциплін та співпраця 3 танцювальними драматургами, задля отримання унікальної суміші художніх бачень у сценічній бальній хореографії; тенденція до використання танцювальної 
драматургії у галузі хореографічної освіти та професійній діяльності танцюристів, як засіб розширення хореографічної перспективи.

Пріоритетним у діяльності хореографа-постановника на сучасному етапі визначено поєднання естетичного досвіду 3 критичним аналізом, цілеспрямоване та активне спостереження за навколишнім середовищем, задля того, аби переступити межі уявлення відомих образів та формувати нові погляди і перспективи.

\section{Jimepamypa}

1. Bauer B. Propensity: Pragmatics and Functions of Dramaturgy in Contemporary Dance. P. Hansen, D. Callison (Eds.) Dance Dramaturgy: Modes of Agency, Awareness and Engagement. London : Palgrave Macmillan, 2015. pp. 31-50.

2. Croft C. A Mutually Satisfying Pas de Deux: Feminist Dramaturgy and Dance in the Undergraduate Dance Curriculum. Theatre Topics. 2009. № 19.2. pp. 181-191. DOI:10.1353/tt.0.0065.

3. Hansen P. An Act of Rendering: Dance and Movement Dramaturgy. Contemporary Theatre Review. 2010. № 20(2). pp. 185-196. DOI: 10.3138/ctr.155.001.

4. Hans-Thies L., Primavesi P. Dramaturgy on Shifting Grounds. Performance Research. 2009. № 14. pp. $3-$ 6. DOI: $10.1080 / 13528160903519468$.

5. Nakajima N. Dance Dramaturgy as a Process of Learning: Koosil-ja's mech[a OUTPUT. P. Hansen, D. Callison (Eds.) Dance Dramaturgy: Modes of Agency, Awareness and Engagement. London : Palgrave Macmillan, 2015. pp. $163-179$.

6. Profeta K. Dramaturgy in Motion: At Work on Dance and Movement Performance. Madison, Wisconsin: The University of Wisconsin Press. 2015. 384 p.

7. Strictly Ballroom. Piccadilly Theatre. URL : https://www.londontheatre.co.uk/show/strictly-ballroom-themusical (дата звернення 15.02.2019).

\section{References}

1. Bauer, B. (2015). Propensity: Pragmatics and Functions of Dramaturgy in Contemporary Dance. P. Hansen, D. Callison (Eds.) Dance Dramaturgy: Modes of Agency, Awareness and Engagement, (pp. 31-50). London : Palgrave Macmillan [in English].

2. Croft, C. (2009). A Mutually Satisfying Pas de Deux: Feminist Dramaturgy and Dance in the Undergraduate Dance Curriculum. Theatre Topics, no. 19.2, pp. 181-191. DOI:10.1353/tt.0.0065 [in English].

3. Hansen, P. (2010). An Act of Rendering: Dance and Movement Dramaturgy. Contemporary Theatre Review, no. 20 (2), pp. 185-196. DOI: 10.3138/ctr.155.001 [in English].

4. Hans-Thies, L., Primavesi, P. (2009). Dramaturgy on Shifting Grounds. Performance Research, no. 14, pp. 3-6. DOI: 10.1080/13528160903519468 [in English].

5. Nakajima, N. (2015). Dance Dramaturgy as a Process of Learning: Koosil-ja'smech[a] OUTPUT. P. Hansen, D. Callison (Eds.) Dance Dramaturgy: Modes of Agency, Awareness and Engagement, (pp. 163-179). London : Palgrave Macmillan [in English].

6. Profeta, K. (2015). Dramaturgy in Motion: At Work on Dance and Movement Performance. Madison, Wisconsin: The University of Wisconsin Press [in English].

7. Strictly Ballroom. Piccadilly Theatre. Available at : https://www.londontheatre.co.uk/show/strictlyballroom-the-musical [in English]. 